\title{
Awareness on Constitutional Rights of Citizens and Form of Protection of Constitutional Rights of Citizens in Indonesia
}

\author{
Tafta Aji Prihandono ${ }^{1}$ and Sri Kusriyah ${ }^{2}$
}

\begin{abstract}
In the Constitution of the Republic of Indonesia of 1945 Article 1 (3) explicitly states that Indonesia is a State of Law. One element that is owned by the state law is the fulfillment of basic human rights as expressed by Friedrich Julius Stahl. Efforts to achieve a constitution that can follow the progress and will meet the basic human rights, the constitution must have a dynamic aspect and were able to capture the phenomenon of historical change, so as to make it as a constitution that is always alive. Only problem is the performance of the Government as the executor of the constitution (executive, legislative and judicial) still do not provide justice and satisfaction for those seeking justice, therefore the necessary awareness of constitutional rights of citizens in Indonesia. Efforts to protect the constitutional rights of Indonesian citizens can be done through the court and non-court lines, and can also via maximize the role of the Constitutional Court to extend its authority. The expansion of the authority of the Constitutional Court may be to accommodate Constitutional Complaint and Constitutional Question.

Keywords: Awareness; Constitutional Rights; Form of Protection.
\end{abstract}

\section{Introduction}

Indonesia is a State of Law. It is as stated in Article 1 (3) of the Constitution of the Republic of Indonesia of 1945. As a State of Law, the State Indonesia adheres to the supremacy of the constitution, namely: the constitution, constitutionality and constitutionalism. The Constitution is the supreme law of the written basis, the constitutionality of an act and act in accordance with the constitution and constitutionalism is understood constitutional citizens. Indonesia country therefore required to conduct a normative and empirical recognition of the rule of law, namely that all problems are resolved with the law as the supreme guideline. Normative recognition of the rule of law embodied in the establishment of legal norms embodied in the establishment of legal norms hierarchical culminating in the supremacy of the constitution. While empirically manifest in the behavior of government and society based on the rule of law. Any action must be based on legislation valid and in writing. Legislation should exist and apply it first or precede actions undertaken. This means that every administrative act must be based on the rule or rules and procedures Legislation should exist and apply it first or precede actions undertaken. This means that every administrative act must be based on the rule or rules and procedures Legislation must exist and apply it first or precede actions undertaken. This means that every administrative act must be based on the rule or rules and procedures ${ }^{3}$.

\footnotetext{
${ }^{1}$ Student of Master of Law, Universitas Islam Sultan Agung Semarang and Regional Secretariat of Kendal, email: tft14w@yahoo.co.id

${ }^{2}$ Faculty of Law Unissula, email: kusriyah@unissula.ac.id

${ }^{3}$ Jimly Asshiddiqie, Konstitusi dan Konstitusionalisme Indonesia, Penerbit Konstitusi Press, Jakarta, 2005, p. 68.
} 
But on the other when the practice of democratic legal state already carried out, often encountered the disappointment of some people who are not satisfied with the implementation of rule by the executive, legislative and judicial. Satjipto Rahardjo in Anis Ibrahim, said the Indonesian legal community are expected to position itself as a lightening has been as slow in capturing and resolving all legal issues are so complex, it has implications for the slow progress in law enforcement ${ }^{4}$. Indeed, the downturn in Indonesian law can not completely shed to the law enforcement, because the current law slump as a result of suboptimal various components of the legal system (legal structure, legal substance, legal culture $)^{5}$ and the most important is the low awareness of the law in all aspects of community life ${ }^{6}$.

The Constitutional Court which has one of the functions of The Guardian of Constitution or as a guardian of the constitution ${ }^{7}$. Has the role as protector of the various efforts made by various parties to violate the constitution either of the Government in the broad sense, or from outsiders who try to violate the constitution. In the development of the Constitutional Court is not yet the maximum buffers do safeguard the constitution. Furthermore, there is a tendency of people and / or entities, who feel that their constitutional rights are violated by the formation of an Act, rollicking file a petition for the Law of the Constitution of the Republic of Indonesia Of 1945 to the Constitutional Court, so impressed the Constitutional Court is the place to accommodate the various weaknesses of the Act $^{8}$.

Although the Constitution protects the general, but the protection of constitutional rights is part of an effort to keep the constitution because the constitutional rights stipulated in the constitution. Efforts to protect constitutional rights have been given to their legal remedies through the mechanism of judicial review by the Constitutional Court as mandated by Article 24C paragraph (1) of the Constitution of the Republic of Indonesia Of 1945. Judicial Review just protect the constitutional rights of citizens of the effort to breach through legal products such as Act, but in case of violations of constitutional rights of citizens by public officials in the implementation of the norms of the Act there is no regulation regarding the settlement and protection.

Based on these considerations above, the the formulation of the problem in this paper is as follows: How did awareness of the constitution (constitutional rights) citizens in Indonesia?; How is the protection of the constitutional rights of citizens in Indonesia?

\section{Discussion}

\subsection{Awareness of Constitutional Rights.}

\footnotetext{
${ }^{4}$ Anis Ibrahim, Merekonstruksi Keilmuan Ilmu Hukum dan Hukum Milenium Ketiga, Malang : In-Trans, 2007, p. 32.

${ }^{5}$ Legal structure means frame, shape permanent, institutional agencies. The legal structure means the institution of the judiciary, the judges, including those associated with the various types of courts. Legal substance is composed of rules and regulations governing the role and behavior of the institution. legal culture means social attitudes and values element that developed in the community.

${ }^{6}$ Lawrence M. Friedman, Sistem Hukum Perspektif IImu Sosial, Bandung : Penerbit Nusa Media, p. 15-19

${ }^{7}$ Tim Penulis, Hukum Acara Mahkamah Konstitusi, Jakarta : Konpress, 2010 p. 10.

${ }^{8}$ Yuliandri, Asas-asas Pembentukan Peraturan Perundang-undangan Yang Baik Gagasan Pembentukan Undang-Undang Berkelanjutan, Jakarta : Raja Grafindo Persada, p. 9.
} 
Before understanding the meaning of Constitutional Rights, should understand the meaning of the Constitution. Etymologically, the term constitution in English is the constitution and constituer in French. The second word is derived from the Latin is the basic constitution, which means the body composition. In the Dutch language term constitution is called grondwet consisting of the word grond means basic and wet word meaning legislation. Then, in the German language the term referred verfassung constitution, the constitution of Republic of Indonesia synonymous with the Constitution. Constitution or the Constitution can be defined ground rules and which contains the basic provisions and be a source of legislation ${ }^{9}$,

Subhi Rajab Mahmassani ${ }^{10}$ Western nations called the Constitution of the constitution (constituo) is derived from the Latin and the first term is used for orders of Roman Emperor (Constitution principum), then it is used in Italy to indicate Constitution (dirritio constututionalle) and from there spread the words of the constitution in various European countries. While the word dustur or laws in Arabic is derived from the Persian language which was originally means the set of laws of King. With this command Daula Ottoman use to set laws for them, while the Constitution they use al Masyrutiyah, because the King is restricted by certain conditions contained therein ${ }^{11}$. In the seventh century of the Prophet Muhammad that have shaped the political system in accordance with the vision of establishing a state religion Medina, power systems and conditions governing the existence of the people poured preformance Medina Medina Charter document or constitution of Medina which was formed in 622 AD Constitution of Medina categorized as enactment constitution written first in which regulate political power, human rights, management of public affairs. Medina Constitution is the document that underlies the formation of a state ${ }^{12}$.

Constitution or the Constitution of the occupies the highest hierarchy in the sort order for the legislation of a State. Constitutie is de hoogste wet ${ }^{13}$. Article 7 paragraph (1) letter a of Act No. 12 Of 2011 on the Establishment of legislation putting the Constitution of the Republic of Indonesia Of 1945 in the highest hierarchy of legislation and regulations. The Constitution is the basic law of the grip of the citizens (the citizen) in the life of society and state. The Constitution not only contains the highest norm (een hoogste normen) but is also a constitutional guidelines (een constitutinale richtnoer) for the people (masses) in the life of society and state ${ }^{14}$, Therefore, the Constitution of the Republic of Indonesia Of 1945 is seen as a form of collective agreement (general agreement) "all the people of Indonesia" that has sovereignty. This brings the consequence that the Constitution of the Republic of Indonesia Of 1945 is the supreme rule in the life of the nation that governs how the sovereignty of the people will be implemented. This is called the supremacy of the constitution as one of

\footnotetext{
${ }^{9}$ Astim Riyanto, Teori Konstitusi, Bandung : Yapemdo, 2000, p. 17-19.

${ }^{10}$ Was taken from the book Subhi Rajab Mahmassani, Konsep Dasar Hak-hak Asasi Manusia, terjemahan Hasanudin), 1993, PT. Tinta Mas, Jakarta, p. 22 in the book of Sri Kusriyah, Negara Hukum dan Konstitusi, Semarang : Unissula Press, 2011, p. 72.

11 Ibid, p. 72.

12 Ibid, p. 101.

13 Laica Marzuki, Kesadaran Berkonstitusi dalam Kaitannya Konstitusionalisme, Jurnal Konstitusi, Volume 6, Nomor 3, September, 2009, p. 19.

14 Ibid.
} 
the main principles upholding democratic constitutional state. In that regard, Solly Lubis argued that the Constitution is the primary source of the norms of constitutional law. Constitution set the shape and composition of the country, tools and equipment at the center of the area, set up tasks that scientific equipment as well as relationships with one another ${ }^{15}$.

People (the citizen) must consciously behave abide by the rules of the constitution in the life of society and state. By being conscious behavior that constitution, the people know the basic rights and human rights as the holder of its sovereignty, rights and obligations as citizens, know and appreciate the implementation of government built on the rule of the people are sovereign. All are there and can be seen in Constitution of the Republic of Indonesia Of 1945. Awareness (bewustzijn) leads one to live something in the act (behavior). Awareness brings appreciation in implementing ${ }^{16}$,

The presence of the constitution is a conditio sine qua non (indispensable condition) for a country. Constitution not only gives an overview and an explanation of the mechanism of state institutions, more than that in it found relational layout and position of the rights and obligations of citizens country ${ }^{17}$. For now almost in all countries characterized by democracy incorporate human rights into the constitution common also referred to as a constitutional right. Constitutional rights are the rights of citizens stipulated in the constitution, the constitutional purpose is formulated in the formulation of the Constitution of the Republic of Indonesia Of 1945.

In a country that has a constitution, human rights contained in the constitution of each country so-called constitutional rights. Citizens' constitutional rights apply only to the person's status as a citizen, while for foreigners is not guaranteed ${ }^{18}$, Strangers apply Article 28 of the Constitution of the Republic of Indonesia Of 1945 which defined the right to life for all people without regard to differences of citizens. Another reason that the exclusion of rights strengthens foreign nationals are also due arrangements regarding the scope of constitutional rights were fewer and narrower of Human Rights. The regulation of constitutional rights are stipulated in the constitution of a country is not always accommodate aspects of human rights contained in the Declaration of Human Right covenants or other rights such as civil and political rights covenant on economic, social and political rights. In addition to the guarantee of human rights ${ }^{19}$. The rights can be categorized as constitutional rights are as follows ${ }^{20}$ :

- Certain human rights are only valid as constitutional rights of Indonesian citizens only. For example, (i) the rights set forth in paragraph D of Article 28 (3) Constitution NRI 1945; (Ii) Article 27 paragraph (2) NRI Constitution of 1945; (Iii) Article 27 paragraph (3); (Iv) Article 30, paragraph (1); (V) Article 31, paragraph (1) NRI Constitution of 1945;

\footnotetext{
${ }^{15}$ M. Solly Lubis, Asas-asas Hukum Tata Negara, Alumni Bandung, 1978, p. 48-49.

${ }^{16}$ Laica Marzuki, op.cit, p. 20.

${ }^{17}$ Majda El-Muhtaj, Hak Asasi Manusia dalam Konstitusi Indonesia, Jakarta : Kencana, 2007, p. 32.

${ }^{18}$ A. Ahsin Thohari, Hak Konstitusional dalam Hukum Tata Negara Indonesia, Jakarta: Erlangga,2016, p. 14.

${ }^{19}$ Asshiddiqie, Presented at the Public Dialogue and the National Consultative Commission of Women "Perempuan dan Konstitusi di Era Otonomi Daerah: Tantangan dan Penyikapan Bersama". Jakarta, 27 November 2007, p. 10.

${ }^{20}$ Ibid, p. $10-11$
} 
- Certain human rights which, although applicable to everyone, but in certain cases, especially for Indonesian citizens apply certain virtues. For example, (i) Article 28D (2) NRI Constitution of 1945; (li) Section 28E (3) Constitution NRI 1945; (lii) Article $28 \mathrm{H}$ paragraph (2) of 1945 Constitution NRI.

- The Right of Citizens to occupy positions that are filled through the election procedure (elected Officials), as President and Vice President, Governor and Deputy Governor, the Regent and Vice Regent, Mayor and Deputy Mayor, the Village Head, Constitutional Court, Supreme Court, members Audit Board, members of consultative institution and representatives that MPR, DPR, DPD and DPRD, the TNI Commander, Chief of Police, the Board of Governors of Bank Indonesia, members of state commissions, and offices are another filled with election procedures, either directly or indirectly by the people.

- The Right of Citizens to be appointed in certain positions (appointed Officials), such as the Indonesian national army, state police, prosecutors, civil servants and their positions within the structural and functional staffing, and other positions are filled by election. Each office (office, ambt, functie) contains rights and obligations as well as the duties and powers that are attached and that the implementation or realization closely associated with the respective officials (official, ambtsdrager, functionaries) as subjects who carry out the job. All the positions in question are valid and can only be occupied by Indonesia's own citizens in accordance with the intent of the provisions of Article 27 paragraph (1) and Article 28D paragraph (3). Article 27 paragraph (1). Article 28D (3) Constitution NRI 1945;

- The right to take legal actions against or sue the decisions of countries assessed harms the constitutional rights concerned citizens. Legal remedies intended to do (i) the decision of the State administration (beschikkingsdaad van de administratie), (ii) the provisions setting (regelensdaad van staat Orgaan), either material or formal, by way of substantive judicial review (materiile toetsing) or procedural judicial review (formele toestsing), or (iii) against the decision of the judge (vonnis) by way of taking it to a higher court institution, namely the level of appeal, appeal, or reconsideration.

With the guarantee of the constitutional right of every citizen of Indonesia in the Constitution of the Republic of Indonesia Of 1945, so should their efforts to the proper functioning of the Constitution of the Republic of Indonesia Of 1945 in the life of society, nation and state that the principles contained in Constitution of the Republic of Indonesia Of 1945 is realized in the reality of life of state and society. This means that the Constitution of the Republic of Indonesia Of 1945 must be implemented seriously by all components of the nation.

\subsection{Form of Protection of Constitutional Rights.}

Protection of constitutional rights can be done through the courts or out of court mechanisms. Protection of constitutional rights through the court system, can be done 
using various types of justice, such as ${ }^{21}$ :

- Protection of constitutional rights through the State Administrative Court, in this case the Constitutional Court. Testing by the Constitutional Court can be done in two ways: through a system of judicial review of the Act against the Constitution of the Republic of Indonesia Of 1945 is called judicial review.

- Protection of constitutional rights through the State Administrative Court or the Administrative Courts. Basic protection carried out by the State Administration officials are due to violation of the constitutional rights of citizens are violated due to the release state administrative official decision that is individualized, concrete, binding and final, arising from the law for a person or legal entity. It can be challenged through the State Administrative Court.

- Protection of constitutional rights through courts Ordinary (regular court). The procedural law applicable in civil or criminal proceedings in addition to functioning as a restriction on freedom of judges as well as a mechanism of protection of the constitutional rights of the parties.

- Protection of constitutional rights through the courts of the Ad Hoc Human Rights. Protection through a court of Human Rights (HAM) is related to the occurrence of serious human rights violations in the past. Then to enforce the law on human rights violations of past gross human rights court be formed Ad Hoc to prosecute human rights violators in the past.

Besides protection made by the court, the constitutional rights of citizens are also protected outside the court mechanism, namely through agencies or commissions an independent State. Agencies or commissions referred to as ${ }^{22}$ :

- Ombudsman of the Republic of Indonesia.

The institute is authorized to oversee the implementation of public service by the Government of the Citizen. The Ombudsman will oversee state agencies that provide public services to protect the interests and rights of citizens are not violated by these public service agencies.

- The National Commission on Human Rights.

National Human Rights Commission was established to protect the human rights protected by the Pancasila and the Constitution of the Republic of Indonesia Of 1945.

\subsection{The role of the Constitutional Court.}

The existence of the Constitutional Court in the constitutional system of Indonesia is to maintain the constitution to be implemented in a responsible manner in accordance with the will of the people and democratic ideals. As the guardian of the constitution, the Constitutional Court serves handling cases-any particular case in the field of administrative (constitution) and in Article 24C of the Constitution of the Republic of Indonesia Of 1945 and the provisions of Article 10 paragraph (1) of Act No. 24 Of 2003

\footnotetext{
21 Heru Setiawan, 2017, Rekonseptualisasi Kewenangan Mahkamah Konsitusi Dalam Upaya Memaksimalkan Fungsi Mahkamah Konstitusi Sebagai The Guardian of Constitution, Faculty of Law of the University of Diponegoro, p. 75-76

22 Ibid, p. 77-78
} 
regarding the Constitutional Court as amended by Act No. 8 of 2011 on the Amendment to Act No. 24 Of 2003 regarding the Constitutional Court, the Constitutional Court has the four powers and the constitutional obligation. Four of authority and an obligation that is: (1) Testing Act against the Constitution; (2) Resolving disputes authorities of state institutions given Constitution; (3) Breaking the dissolution of political parties; (4) Breaking the general election result disputes; and (5) Mandatory disconnect opinion of Parliament on alleged violations by the President and / or Vice President by the Constitution of the Republic of Indonesia Of 1945.

Through constitutional case decisions are handled based on four of the Constitutional Court and the constitutional obligation of the authority, the Constitutional Court has been instrumental in the constitution embodies the real life of the country, namely "uphold the constitution". As the enforcement of the constitution, the Constitutional Court concerned foster constitutional awareness in society and among state officials that are not accustomed to taking shortcuts or vigilante resolve conflicts or problems in the practice of constitutional and political life of the country.

Then with the role of the Constitutional Court through the four authorities and of the obligations is expected to protect the constitutional rights of Indonesian citizens. Protection of the constitutional rights of Indonesian citizens by the Constitutional Court in order to get more leverage should need any additional authority and Constitutional Question Constitutional Complaint to the Constitutional Court ${ }^{23}$,

According to Moh. Mahfud $\mathrm{MD}^{24}$, Meaning Constitutional Complaint is filing the case to the Constitutional Court for violations of constitutional rights which no legal instrument or it's no longer available casing upon completion lane law / justice ${ }^{25}$, Some countries are already doing provisions such as the German constitutional complaint. German Constitution Article 93 paragraph (1) point 42 explicitly states that the German Federal Constitutional Court is authorized constitutional complaint. Definition of Constitutional Question is a review mechanism or testing of a rule of law raised by the judge who was hearing a case, and in the judicial process that comes the question of the constitutionality of the provisions of the rule of law to be used in assessing and taking the decision. Mechanism constitutional question, it is also required as part of efforts to ensure the supremacy of the constitution and the protection of citizens' constitutional rights. The function of the mechanism of constitutional question is: (1) avoid the presence of the judge's decision is contrary to the constitution and violates the constitutional rights of citizens; (2) gives the testing room to the legislation more widely, especially court judge is a profession that has more capacity to investigate the possibility of a conflict of norms; and (3) to avoid any violation of constitutional rights that are not needed for judicial review must wait for a court decision or judicial proceedings be suspended ${ }^{26}$.

\footnotetext{
${ }^{23}$ Ibid, p. 162

${ }^{24}$ Moh. Mahfud MD, 2010, Konstitusi dan Hukum dalam Kontroversi Isu, Jakarta : PT Radja Grafindo, 2010, p. 287.

${ }^{25}$ I dewa Gede Palguna, Constitutional Question : Latar Belakang dan Praktek di Negara Lain serta Penerapannya di Indonesia, Jurnal Hukum No. 1, Volume 01, p. 137-138.

26 Mohamad Ali Safaat, Menggagas Constitutional Question di Indonesia, Paper presented at the National Seminar on cooperation Brawijaya University General and the secretariat of the Constitutional Court with the Center for Constitutional Studies Faculty of Law, University of Brawijaya, 2009, p, 1
} 
Countries that have implemented the mechanism of constitutional question, especially countries that adhered to the test of constitutional rule of law through the courts Constitutional Court. Mechanism constitutional question in some countries is one mechanism for judicial review. Constitutional Question is granting to the court to file constitutional questions to the Constitutional Court. Countries Croatia set up a mechanism constitutional question in Section IV "Review of the Constitutionality of Laws and the Constitutionality and Legality of Other Regulations Croatian Constitutional Act. Article 35 paragraph (1) states that when the court found that the rule of law being applied is not in accordance with the constitution, the case should be frozen and posed the question to the Constitutional Court.

Act No. 24 Of 2003 regarding the Constitutional Court, as amended by Act No. 8 of 2011 on the Amendment to Act No. 24 Of 2003 regarding the Constitutional Court will be the second change, it is as stated in the 2018 Prolegnas Priority ${ }^{27}$. However, it appears that the substance of the material in the Draft Law on the Second Amendment to Act No. 24 Of 2003 regarding the Constitutional Court has not expand the authority of the Constitutional Complaint and Constitutional Question on the authority of the Constitutional Court. Similarly, Article 24C paragraph (1) of the Constitution of the Republic of Indonesia Of 1945, certainly needs amendments.

\section{Closing}

\subsection{Conclusion.}

- The Constitution is the supreme law of the written basis, the constitutionality of an act and act in accordance with the constitution and constitutionalism is understood constitutional citizens. Build awareness of the constitution is not an easy task and requires a long time, as well as dealing with various obstacles.

- Substantially functioning of the Constitution of the Republic of Indonesia Of 1945 in the life of society, nation and state, by applying the principles of the constitutional rights contained in the Constitution of the Republic of Indonesia Of 1945 in the reality of the life of state and society. This means that the Constitution of the Republic of Indonesia Of 1945 must be implemented seriously by all components of the nation.

- A form of protection of constitutional rights Indonesian citizen can be done through the court and non-court.

\subsection{Suggestion}

- The Constitutional Court (MK) as the state institutions stipulated in the Constitution of the Republic of Indonesia Of 1945 and Act No. 24 Of 2003 regarding the Constitutional Court, as amended by Act No. 8 of 2011 on the Amendment of Act Number 24 of 2003 regarding the Constitutional Court in principle only has four authority and the obligation: (1) Testing Act against the Constitution; (2) Resolving

\footnotetext{
27 National Legislation Program, hereinafter referred Legislation is planning instrument formation program arranged Act in a planned, integrated and systematic. Article 1 point 9 of Act No. 12 of 2011 on the Establishment of Legislation. accessed fromhttp://www.dpr.go.id/uu/prolegnas on October 31, 2018
} 
disputes kewenangannnya authorities of state institutions given the Constitution; (3) Breaking the dissolution of political parties; (4) Breaking the general election result disputes; and (5) Mandatory disconnect opinion of Parliament on alleged violations by the President and / or Vice President by the Constitution of the Republic of Indonesia Of 1945.

- Making changes to Article 24C paragraph (1) of the Constitution of the Republic of Indonesia Of 1945, by extending the authority of the Constitutional Court is to facilitate the Constitutional Complaint and Constitutional Question.

\section{Bibliography}

\section{Book}

[1] Ahsin Thohari, Hak Konstitusional dalam Hukum Tata Negara Indonesia, Jakarta: Erlangga,2016.

[2] Anis Ibrahim, Merekonstruksi Keilmuan IImu Hukum dan Hukum Milenium Ketiga, Malang : In-Trans, 2007.

[3] Astim Riyanto, Teori Konstitusi, Bandung : Yapemdo, 2000.

[4] Heru Setiawan, 2017, Rekonseptualisasi Kewenangan Mahkamah Konstitusi Dalam Upaya Memaksimalkan Fungsi Mahkamah Konstitusi Sebagai The Guardian of Constitution, Tesis Fakultas Hukum Univeristas Diponegoro.

[5] Jimly Asshiddiqie, Konstitusi dan Konstitusionalisme Indonesia, Penerbit Konstitusi Press, Jakarta, 2005.

[6] Lawrence M. Friedman, Sistem Hukum Perspektif IImu Sosial, Bandung : Penerbit Nusa Media.

[7] Laica Marzuki, Kesadaran Berkonstitusi dalam Kaitannya Konstitusionalisme, Jurnal Konstitusi, Volume 6, Nomor 3, September, 2009.

[8] M. Solly Lubis, Asas-asas Hukum Tata Negara, Alumni Bandung, 1978.

[9] Majda El-Muhtaj, Hak Asasi Manusia dalam Konstitusi Indonesia, Jakarta : Kencana, 2007.

[10] Moh. Mahfud MD, 2010, Konstitusi dan Hukum dalam Kontroversi Isu, Jakarta : PT Radja Grafindo, 2010.

[11] Sri Kusriyah, Negara Hukum dan Konstitusi, Semarang : Unissula Press, 2011.

\section{Website}

http://www.dpr.go.id/uu/prolegnas accessed on October 31, 2018.

\section{Legislation}

[1] Constitution of the Republic of Indonesia 1945.

[2] Act No. 24 Of 2003 regarding the Constitutional Court.

[3] Act No. 8 of 2011 on the Amendment to Act No. 24 Of 2003 regarding the Constitutional Court.

[4] Act No. 12 Of 2011 on the Establishment of Legislation. 


\section{Journal}

[1] Jimly Asshiddiqie, Disampaikan pada acara Dialog Publik dan Konsultasi Nasional Komnas Perempuan "Perempuan dan Konstitusi di Era Otonomi Daerah: Tantangan dan Penyikapan Bersama". Jakarta, 27 November 2007.

[2] Mohamad Ali Safaat, Menggagas Constitutional Question di Indonesia, Makalah disampaikan pada acara Seminar Nasional di Universitas Brawijaya Malang kerja sama Sekjen dan kepaniteraan Mahkamah Konstitusi dengan Pusat Pengkajian Konstitusi Fakultas Hukum Universitas Brawijaya Malang, 2009. 